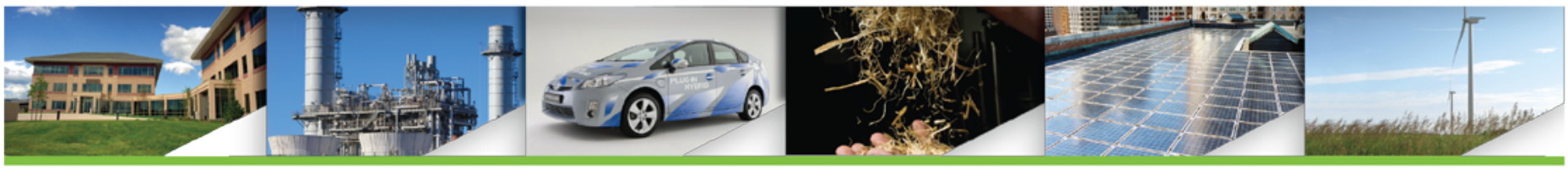

\title{
Multi-Metric Sustainability Analysis
}

Shannon Cowlin, Donna Heimiller, Jordan Macknick, Margaret Mann, and Jacquelyn Pless

National Renewable Energy Laboratory

David Munoz

Colorado School of Mines

The Joint Institute for Strategic Energy Analysis is operated by the Alliance for Sustainable Energy, LLC, on behalf of the U.S. Department of Energy's National Renewable Energy Laboratory, the University of Colorado-Boulder, the Colorado School of Mines, the Colorado State University, the Massachusetts Institute of Technology, and Stanford University.

Technical Report

NREL/TP-6A50-61719

December 2014

Contract No. DE-AC36-08GO28308

MNREL O Coloradoschoolorermes 


\section{Multi-Metric Sustainability Analysis}

Shannon Cowlin, Donna Heimiller, Jordan Macknick, Margaret Mann, and Jacquelyn Pless

National Renewable Energy Laboratory

David Munoz

Colorado School of Mines

Prepared under Task Nos. 6A50.1010 and 6A50.3010

The Joint Institute for Strategic Energy Analysis is operated by the Alliance for Sustainable Energy, LLC, on behalf of the U.S. Department of Energy's National Renewable Energy Laboratory, the University of Colorado-Boulder, the Colorado School of Mines, the Colorado State University, the Massachusetts Institute of Technology, and Stanford University.

JISEA $^{\circledR}$ and all JISEA-based marks are trademarks or registered trademarks of the Alliance for Sustainable Energy, LLC.

The Joint Institute for Strategic Energy Analysis 15013 Denver West Parkway Golden, CO 80401 303-275-3000 • www.jisea.org
Technical Report

NREL/TP-6A50-61719

December 2014

Contract No. DE-AC36-08GO28308 


\section{NOTICE}

This report was prepared as an account of work sponsored by an agency of the United States government. Neither the United States government nor any agency thereof, nor any of their employees, makes any warranty, express or implied, or assumes any legal liability or responsibility for the accuracy, completeness, or usefulness of any information, apparatus, product, or process disclosed, or represents that its use would not infringe privately owned rights. Reference herein to any specific commercial product, process, or service by trade name, trademark, manufacturer, or otherwise does not necessarily constitute or imply its endorsement, recommendation, or favoring by the United States government or any agency thereof. The views and opinions of authors expressed herein do not necessarily state or reflect those of the United States government or any agency thereof.

Available electronically at http://www.osti.gov/bridge

Available for a processing fee to U.S. Department of Energy and its contractors, in paper, from:

U.S. Department of Energy

Office of Scientific and Technical Information

P.O. Box 62

Oak Ridge, TN 37831-0062

phone: 865.576.8401

fax: 865.576 .5728

email: mailto:reports@adonis.osti.gov

Available for sale to the public, in paper, from:

U.S. Department of Commerce

National Technical Information Service

5285 Port Royal Road

Springfield, VA 22161

phone: 800.553 .6847

fax: 703.605.6900

email: orders@ntis.fedworld.gov

online ordering: http://www.ntis.gov/help/ordermethods.aspx

Cover Photos: (left to right) PIX 04135, iStock 22779761, PIX 16933., PIX 15648, PIX 08466, PIX 21205

NREL prints on paper that contains recycled content. 


\section{Table of Contents}

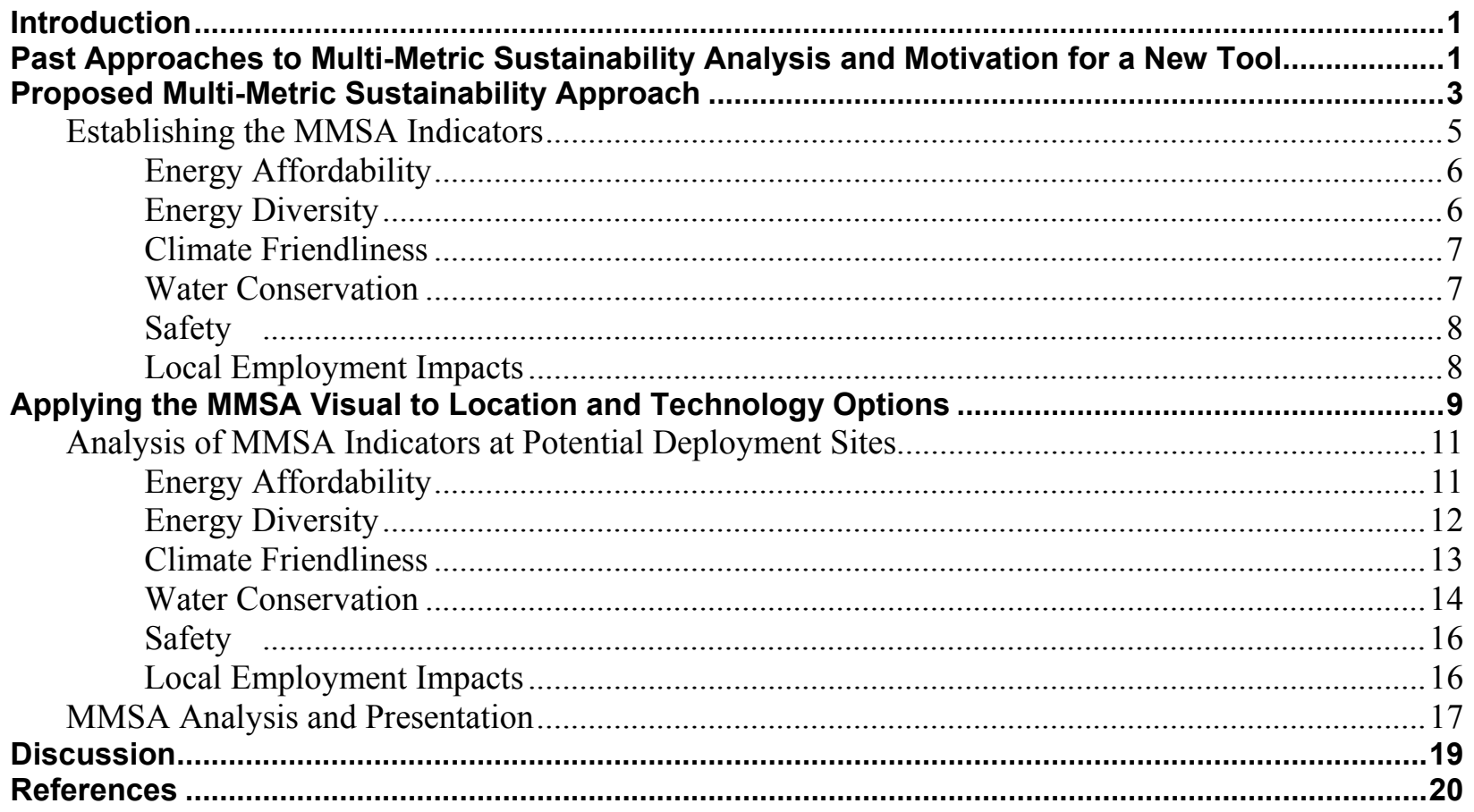

\section{List of Figures}

Figure 1. In this proposed visual tool for MMSA, larger ruler lengths represent more positive

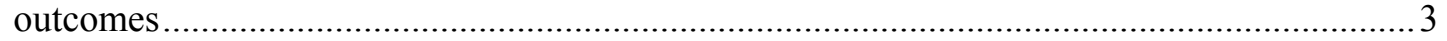

Figure 2. Conceptual comparison using the visual tool for MMSA ........................................................

Figure 3. Extraction areas used for the multi-metric sustainability analysis ........................................... 10

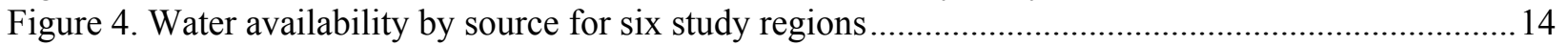

Figure 5. Water consumption by site for utility-scale PV installation ............................................... 15

Figure 6 . Water consumption impacts of a variety of electricity generating technologies ........................ 16

Figure 7. MMSA visual showing case study findings......................................................................... 18

\section{List of Tables}

Table 1. Potential Indicators for Use in Multi-Metric Sustainability Analysis ......................................... 4

Table 2. Features of the Multi-metric Sustainability Analysis Case Study Sites ....................................11

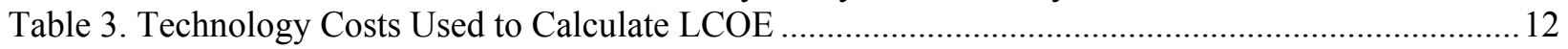

Table 4. LCOE for Onshore Wind and Solar PV at Six Case Study Sites ..............................................12

Table 5. Potential Solar and Wind Generation on Case Study Sites ......................................................13

Table 6. Baseline Diversity Indicator for Each Case Study Site and the Percent Change in

Diversity Indicator under Wind and Solar Project Development Scenarios.......................... 13

Table 7. Local Employment Impacts from Deployment of Wind and Solar Projects at Six Land

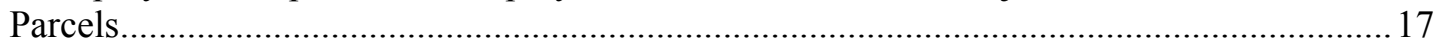

Table 8. Summary of MMSA Indicators, Metrics, and Range of Values ................................................ 17

Table 9. Metric Values for Each Scenario and Land Parcel ................................................................. 18 


\section{Acknowledgments}

The authors thank the Joint Institute for Strategic Energy Analysis for funding this research through its Innovative Research Analysis Award Program. They also appreciate the support and assistance of Patricia Statwick, Yimin Zhang, Jaquelin Cochran, Scott Gossett, Kendra Palmer, Karin Haas, and Dean Armstrong. 


\section{Introduction}

Common metrics for comparing energy technologies - such as the levelized cost of energy (LCOE), greenhouse gas (GHG) emission profiles, and criteria air pollutant emissions - are instructive, but they are not always sufficient on their own for informing policy or investment decisions. For instance, although costs per unit of output (levelized costs) can provide a baseline guide and encourage or redirect investment (Gross et al., 2009), they are less applicable in markets characterized by a diverse range of technology options and an uncertain future (Awerbuch, 2004). There are often many other factors to consider when seeking to fully explore the potential impacts of an energy project. Policy and investment decisions often take into account a combination of social, environmental, and economic factors that vary in priority by jurisdiction. Use of a readily accessible framework that allows for evaluating impacts and comparing tradeoffs among these factors in energy policy, expansion planning, and investment decision-making is needed.

Recognizing this, the Joint Institute for Strategic Energy Analysis (JISEA) funded this exploration of multi-metric sustainability analysis (MMSA) to provide energy decision makers with a means to make more comprehensive comparisons of energy technologies, with a focus on the policymaker's perspective.

The resulting MMSA tool allows decision makers to simultaneously compare energy technologies and potential deployment locations according to several sustainability indicators. For simplicity, the project team chose six possible indicators - two social, two environmental, and two economic indicators. However, the designers intend for this visual comparison tool to be scalable and adaptable to unique local needs. Similarly, the tool is designed so that trade-offs between technology and locations options can be easily interpreted.

This analysis reviews the state of MMSA, explains the methodology for developing the new MMSA tool, tests the concept by evaluating two energy technologies at six different U.S. locations, and discusses potential directions for additional work.

\section{Past Approaches to Multi-Metric Sustainability Analysis and Motivation for a New Tool}

Previous efforts to provide comprehensive assessments of energy development options have primarily analyzed historic energy installations or system-wide sustainability. One set of studies assessed the performance of energy projects on various sustainability scales through retrospective investigation (Begic and Afgan 2007). Evans et al. (2009) evaluated the sustainability of renewable power generation technologies by qualitatively assessing performance against a range of sustainability indicators, translating those to a 1 to 4 scale and summing over all categories for a total sustainability ranking. While these system-wide assessments can provide insight into the general nature of technologies and systems, and they can be perhaps adapted for prospective evaluation, they cannot be directly translated into impacts for specific proposed projects. 
Other research has applied multi-criteria analysis, using normalization and weighting to aggregate findings into one metric (Lior 2007; Afgan et al. 2000; Afgan and Carvalho 2002; Pehnt 2006). The resulting ordered ranking of options allows stakeholders to choose the "best" options. While the ranked list is straightforward and easy to understand, aggregated indicators do not allow for comparisons of trade-offs, nor do they reflect differing value judgments and prioritization of individual metrics by various stakeholders. In other words, using a single metric to evaluate energy development options does not allow for comprehensive consideration of other potential project costs and benefits that may be important, such as environmental, social, and economic impacts, and trade-off analysis.

Other approaches to measuring project sustainability have been developed, particularly with the use of spider diagrams. For instance, in the mid-1990s, Elkington (1994) built a framework for measuring performance in corporate America. This analysis was termed the triple bottom line and extended the traditional business performance measures, such as return on investment and profits, to environmental and social dimensions. The triple bottom line focuses on business-oriented applications. However, a similar approach can be used to assess energy project development along environmental, social, and economic impacts, and other measurements of concern to policymakers and other stakeholders (i.e., local employment impacts, climate friendliness).

Convertino et al. (2013) propose the use of multi-criteria decision analysis methods to select optimal metric sets, but they focus on design and monitoring of sustainable ecosystem restorations as opposed to energy technologies.

One sophisticated use of the spider diagram methodology is the Arup SPeAR model (Arup 2014), which applies the United Kingdom's Government's Sustainable Development Indicators and the Global Reporting Initiative (GRI) indicators within its project appraisal framework. Spear has been modified to be applicable at an international scale. The method incorporates a color scheme for varying degrees of indicator magnitude, and it offers a unique visual for communicating results. Furthermore, a framework for integrated sustainability analysis developed at the University of Sydney comprises a range of environmental, economic, and social indicators as a triple bottom line analysis illustrated in a spider diagram (Dey n.d.).

The range of tools developed in this field reflects the complexity associated with measuring sustainability. The objective of this research is to propose an option that is particularly intuitive - offering the benefit of ease of interpretation. Furthermore, the proposed methodology is unique in that it allows the user to readily and consistently compare technology and location options for a given project. By presenting multiple dimensions of sustainability simultaneously and in an easily understandable manner, this visual will offer decision-makers an option for quickly evaluating trade-offs, and in a way that is adaptable to a wide variety of scenarios and priorities.

The MMSA is designed to offer a readily-accessible and adaptable framework for comparing tradeoffs. Therefore, the goal of this pilot analysis is to develop a tool that allows policymakers to assess an array of energy project development options within the 
context of their unique local needs and priorities, and to demonstrate its application in a specific case study.

\section{Proposed Multi-Metric Sustainability Approach}

As noted, one objective of this study was to develop a means of presenting multiple indicators in a disaggregated format for easy interpretation by a diverse stakeholder group. Given that the sustainability indicators may vary in priority from one case to the next, a second objective was for the approach to be adaptable to a wide variety of scenarios.

Figure 1 illustrates the design selected for further evaluation. Each indicator is presented as a ruler, where a longer ruler indicates a more positive outcome - offering the ease of a "bigger is better" type of interpretation. Indicators from each sustainability category (social, environmental, and economic) are included, and indicators within categories are adjacent and presented with similar color schemes. This graphic allows for straightforward visual comparisons of trade-offs faced when considering specific projects and technology options. The graphic could also be used to compare different project scenarios at one or many locations, as shown in Figure 2.

The indicators selected for this analysis were selected based on a policymaker's perspective. For instance, policymakers are likely to be concerned about employment effects of a project (and thus it is included as criteria here), however project developers may be less likely to consider employment in their project investment assessments. To account for varying priorities, a different set of potential indicators can be considered when assessing technology options.

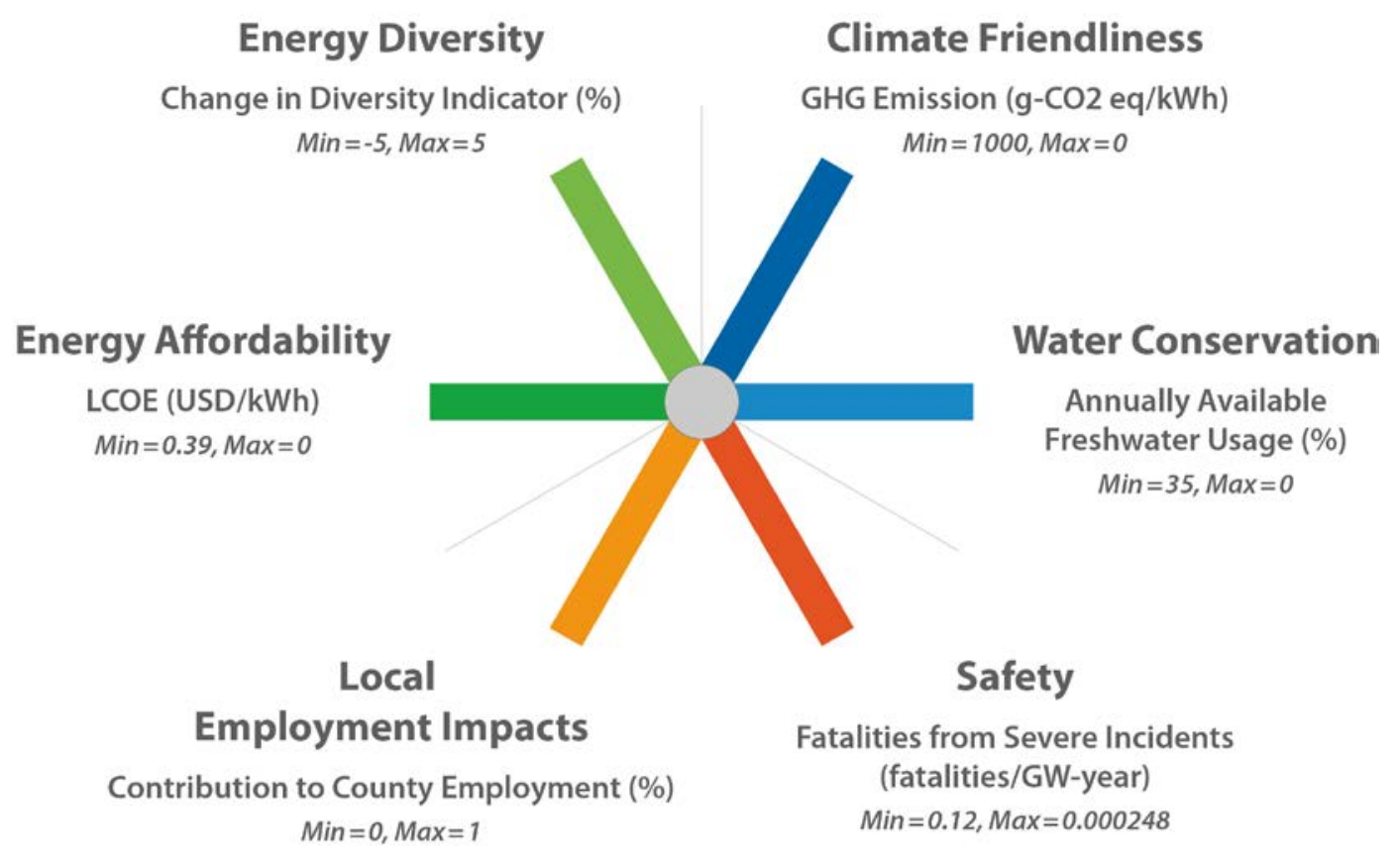

Figure 1. In this proposed visual tool for MMSA, longer ruler lengths represent more positive outcomes 


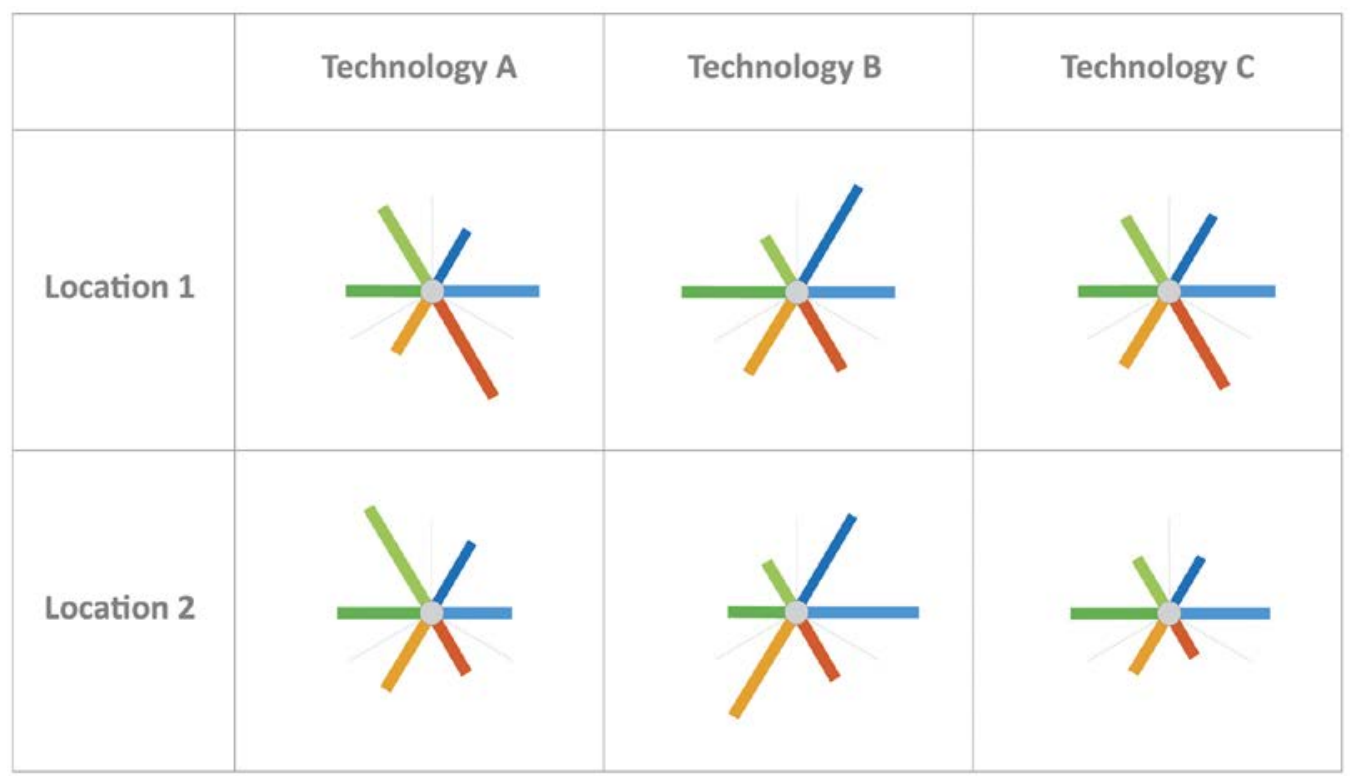

Figure 2. Conceptual comparison using the visual tool for MMSA

Figure 1 presents six sustainability indicators that could have relevance for an energy project that is considering tradeoffs among three technologies and two locations. There are many more indicators that might be of interest and importance to various stakeholders. A broader list of potential indicators is presented in Table 1. Note that some of the indicators, such as employment and industry expansion, are categorized as economic indicators, but these may be relevant social indicators as well if local impacts are considered (rather than strictly macro-economic impacts).

Table 1. Potential Indicators for Use in Multi-Metric Sustainability Analysis

\begin{tabular}{|l|l|l|}
\hline Economic & Environmental & Social \\
\hline Cost of energy & GHG emissions & Health impacts \\
Employment & Biodiversity & Education opportunities and \\
Industry expansion & Water use and impact & needs \\
Trade impacts & Air quality & Gender impacts \\
Energy imports and security & Land use impacts & Rural development \\
Market demand & Soil health & Energy access \\
Climate resilience & & Safety and security \\
& & Energy security \\
& & Food security \\
& & Cultural preservation \\
\hline
\end{tabular}

The proposed visual presents very different indicators in the same manner, which means that each indicator has a customized axis based on the metric chosen to represent that indicator. To ensure cross-comparability, axis minimums and maximums are established so that they correspond to the worst and best possible expected outcomes, respectively, for both fossil and renewable technologies. In some cases, the indicators may seem 
counter-intuitive: instead of larger indicator values always representing a more favorable result, smaller indicator values may represent the best possible expected outcome. For example, LCOE values are more favorable for Energy Affordability when these values are smaller, indicating a lower cost for a given unit of energy output. Thus the smallest possible LCOE value represents the best-expected outcome, and accordingly, is shown as the axis maximum. Care must be taken to understand each axis' underlying metric.

Ideally, all indicators should be assessed quantitatively. However, some variables, including some social variables, are inherently more difficult to quantify than others (Francis n.d.). In these cases, reasonable proxies and quantification estimation methods that have been generally applied in the related literature can be used. When that may not be possible, users may want to use shading or another visual modification to designate indicators that are assessed qualitatively.

One advantage of this graphic is that the independent impacts are discretely illustrated, and so trade-offs across technology choice and location can be compared in light of policymaking priorities (as opposed to one indicator that aggregates all impacts without opportunity to prioritize objectives). Additionally, estimates of uncertainty for each impact can be expressed as error bars or illustrated intervals on the edge of each ruler.

A potential challenge when using this graphical representation is the sensitivity of results and their interpretations to changes in the defined upper and lower bounds on each axis. The selection of high and low bounds and using a linear scale inherently weights each of the criteria; using drastically different bounds could lead to different relative benefit interpretations. For instance, if the upper bound on the LCOE is set to be lower than its original designation, then the magnitude of that indicator may change relative to the other indicators. It is important for the user to keep these implications in mind when determining axes bounds. For consistency, the standard adopted in the application here is to select bounds based on best and worst possible expected outcomes that are generally recognized in the field.

\section{Establishing the MMSA Indicators}

For this pilot of the proposed MMSA visual, the authors limited the scope to six indicators relevant for specific sites and technologies. The team chose two indicators from each sustainability category:

- Economic: energy affordability and energy diversity

- Environmental: climate friendliness and water conservation

- Social: safety and local employment impacts.

Table 8, which appears later in this text, summarizes the MMSA indicators and range of values. The following discussion addresses the specific indicators chosen and details assessment methodologies and determination of maximum and minimum values applied in this case study. The specific metrics were selected for illustrative purposes, but the model can be customized to include indicators that are particularly relevant for a variety of stakeholders. 


\section{Energy Affordability}

The cost of electricity can determine a project's economic viability, and so it is included here as one of the economic indicators as measured by LCOE in U.S. dollars (USD) per kilowatt-hours (kWh) to represent energy affordability. The authors assumed that the most costly utility-scale renewable energy electricity generation would be the most expensive considered, thus defining the worst expected outcome and the axis minimum.

The Intergovernmental Panel on Climate Change (IPCC) Special Report on Renewable Energy (SRREN) presents LCOE estimates for renewable technologies using discount rates of 3\%,7\%, and 10\%, respectively (IPCC 2011); this current analysis only considers estimates produced assuming a $3 \%$ discount rate. ${ }^{1}$ The maximum LCOE value for utilityscale renewable technologies served as the upper-bound for one-axis solar photovoltaics (PV). This value of $\$ 0.39 / \mathrm{kWh}$ is the maximum LCOE value included, corresponding to the minimum energy affordability value. The minimum LCOE value was set to $\$ 0.00 / \mathrm{kWh}$, representing maximum energy affordability.

These costs do not include the cost of financing, integration, or transmission, nor do they include potential revenue streams, such as from the sale of renewable energy certificates (RECs), though these could be included, if desired, and data are available.

\section{Energy Diversity}

The security of energy supply sometimes drives promotion of specific energy strategies. A secure energy supply is defined differently by various groups but is generally agreed to exhibit the characteristics of availability (physical), accessibility (geopolitical), affordability (economic), and acceptability (environmental) (Sovacool 2010). A variety of indicators have been established and applied to evaluate these different elements of energy security, some individual and others aggregated.

While import dependency and geopolitical risk might also be important in a regional sense, this analysis uses a simple diversity indicator to assess the potential impact of a proposed project on a region's energy security. Because diversity can indicate a system's resilience to supply disruption and price volatility, it is a reasonable proxy for energy security.

To measure diversity, the Shannon Diversity Index is used, where $p_{i}$ is the fractional share of a utility's electricity generation off-take from energy source $i$ (Jansen et al. 2004). Assuming all generation comes from coal, natural gas, petroleum, hydroelectric, nuclear, biomass, geothermal, wind, and solar, maximum diversity reflects generation that is evenly spread across all nine energy sources (i.e., $p_{i}=0.111$ ), which yields a diversity indicator value of $2.20 .{ }^{2}$ Minimum diversity indicates that all generation comes

\footnotetext{
${ }^{1}$ Although a $3 \%$ discount rate would be considered low for project analysis from the viewpoint of an investor or developer, it is the commonly applied social discount rate and is used in this analysis since a policymaker's perspective is assumed. The normal discount rate selection implications apply to the results presented.

${ }^{2}$ This calculation comes from the Shannon Diversity Index, which is found as

$$
H=-\sum_{i=1} p_{i} \ln p_{i}
$$
}


from one source and yields a diversity indicator of 0 . As projects assessed under this method are unlikely to result in a complete restructuring of an energy system, the impact scale preliminarily is set to range from a $5 \%$ decrease to a $5 \%$ increase in the diversity indicator.

\section{Climate Friendliness}

Because climate change may motivate some clean energy investments, the potential impact on climate was chosen as an indicator as measured by life cycle GHG emissions in grams $(\mathrm{g})$ of carbon dioxide equivalent $\left(\mathrm{CO}_{2}\right.$-eq) per $\mathrm{kWh}$. The scale was set based on recent GHG harmonization analysis published in the IPCC SRREN (IPCC 2011).

The range of 'climate friendliness' median values ranged from $4 \mathrm{~g} \mathrm{CO}_{2}$-eq $/ \mathrm{kWh}$ for hydropower to $1,001 \mathrm{~g} \mathrm{CO}_{2}$-eq $/ \mathrm{kWh}$ for coal. Therefore, the climate friendliness range in this case study was set to roughly correspond to these figures with minimum and maximum values of 0 and $1,000 \mathrm{~g} \mathrm{CO}_{2}$-eq/ $\mathrm{kWh}$, respectively. This range includes only the span of median values reported and not the entire range of possible values; however, current deployments would likely employ modern, high-efficiency designs, and associated emissions are unlikely to be higher than the median values.

\section{Water Conservation}

Water availability and competing demands for water resources can be a constraint for energy project development. Although the technologies selected for comparison in this study have relatively low water requirements compared to other electricity generating technologies (Macknick et al. 2011), water conservation was chosen as one of the environmental metrics for this MMSA to illustrate its relevance and applicability to a wide variety of technologies. Both water resources and water uses are distributed unevenly throughout the United States, meaning any assessment of water use at a proposed site needs to consider local water availability.

Water availability can be defined in a variety of ways, depending on what types of water are included (e.g., surface freshwater, fresh groundwater, brackish groundwater, municipal wastewater) and to what degree state and local regulations and legal requirements are considered. In places where freshwater resources are stressed, municipal wastewater and brackish groundwater sources can be used for electricity operations, though this incurs an additional cost and performance penalty (EPRI 2003).

For the purpose of this analysis, we define water availability as described by Tidwell et al. (2014), which considers physical and legal availability associated with a variety of freshwater sources, brackish groundwater, and municipal wastewater, on a U.S. Geological Survey (USGS) hydrologic unit code (HUC) 8-level (Seaber et al. 1987). Water availability for each site in this study was determined by identifying the water availability characteristics of the HUC-8 region in which it is located. The water conservation metric used here is defined as the fraction of annually available freshwater (surface water and groundwater) that would be required for operations at the energy facility. If the facility can offset its freshwater usage by utilizing municipal wastewater or brackish groundwater for operations, that non-freshwater usage lowers the impact on water availability. 
The water conservation range was set from zero to one, with a zero value representing no available water required for operations for maximum water conservation; a value of one indicates that all available water is required for operations (representing the minimum value - the worst expected outcome - for water conservation for the purposes of the MMSA visual).

\section{Safety}

Based on the importance of risks to workers and project acceptance by local community members, safety was identified by the team as a social indicator that may be of interest to policymakers. The specific metric chosen is based on recent research that explored fatality-based indicators across fossil, nuclear, and renewable technologies for the IPCC SRREN (IPCC 2011). Fatalities from severe incidents ( $>5$ fatalities) were selected due to data reliability and importance in public perception, which were normalized to electricity production in Gigawatt electrical years (GWe-years).

All Organization for Economic Cooperation and Development (OECD) estimates for fossil technologies, the lower-limit total fatalities for Generation II nuclear facilities, and the full range across renewable technologies were included. Reported fatality rates ranged from 0.000245 fatalities $/ \mathrm{GW}_{\mathrm{e}}$-yr for PV, to 0.12 fatalities/GWe-yr for coal (IPCC 2011). In the MMSA visual, these values represent the maximum (best expected outcome) and minimum (worst expected outcome) levels of safety corresponding to fatality risk for the safety indicator's axis.

\section{Local Employment Impacts}

Given the importance of local employment opportunities to securing community support for energy projects, particularly from a policymaker's perspective, local employment impact is included as a social metric in this pilot analysis. Many utility-scale renewable energy projects are developed in rural areas where employment opportunities may be scarce, with the potential for increasing urban migration. Though the absolute number of jobs associated with one energy development project may be small relative to the overall economy, the impact of increased jobs may be significant in some regions.

For this analysis, the local employment impact is defined as the number of nonconstruction direct jobs created in the community divided by the county's labor force. The maximum value would be 1 if a project were responsible for all jobs in the county, but as projects will not typically reach across an entire county, the maximum impact value (best expected outcome) is set to $1 \%$ of all jobs for the purposes of these preliminary analyses. The minimum value (worst expected outcome) is set to $0 \%$, although it is important to note that macro-level jobs analysis may indicate a net negative jobs result and might be a consideration if conducting this MMSA from a macro-level perspective. 


\section{Applying the MMSA Visual to Location and Technology Options}

To test how the MMSA visual would work to evaluate potential energy development projects, two different technologies were evaluated at six different locations. Areas were selected based on a recent study of U.S. technical potential for renewable technologies (Lopez et al. 2012). This analysis identified all land area in the United States deemed suitable for utility-scale wind and solar development after screening for terrain slope restrictions, appropriate land use categories, environmental factors, and minimum wind resource intensity at $80 \mathrm{~m}$ hub height.

These lands were overlaid with a geospatial dataset identifying Bureau of Land Management (BLM) and tribal-owned lands, and six 18-km2 parcels were identified with sufficient area, based on the screening criteria, to support at least $50 \mathrm{MW}$ of wind, assuming a deployment density of $5 \mathrm{MW} / \mathrm{km} 2$. Two potential sites, one BLM and one tribal, were chosen in each of Wyoming, Idaho, and Arizona. The potential development sites are shown in Figure 3 as "extraction areas." The areas' features are presented in Table 2, which also lists the specific tribes owning land designated as under the control of the Bureau of Indian Affairs (BIA). Also shown in Table 2 is the amount of the land from the initial screening area available for PV and wind development. 


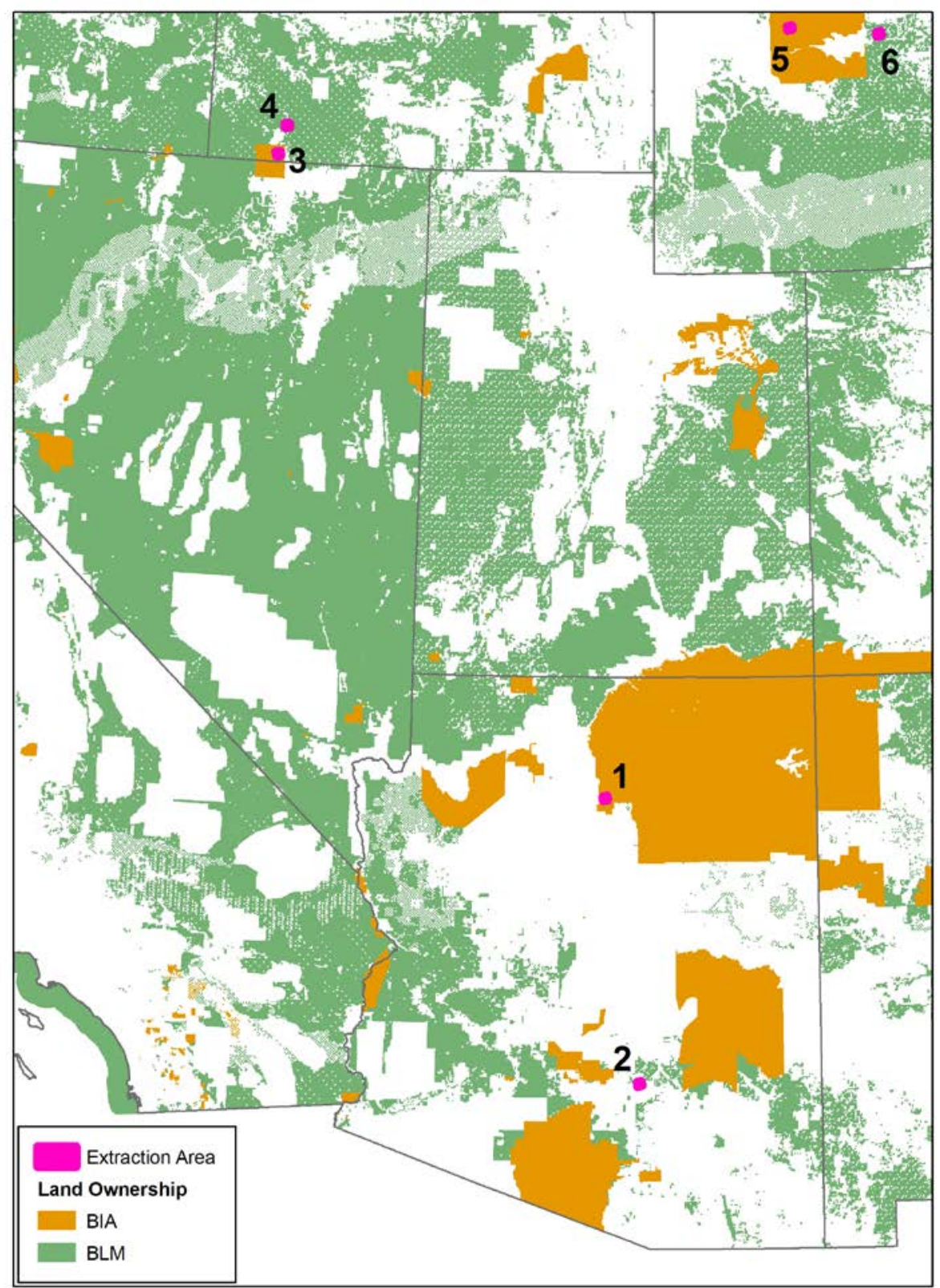

Figure 3. Extraction areas used for the multi-metric sustainability analysis

The region shown is the southwest United States, with extraction areas in Arizona, Idaho, and Wyoming. BIA denotes tribal ownership, and BLM denotes ownership by the federal government. The pink extraction areas show the locations selected for analysis. 
Table 2. Features of the Multi-metric Sustainability Analysis Case Study Sites

\begin{tabular}{|llllll|}
\hline Area ID & Ownership & $\begin{array}{l}\text { Available } \\
\text { PV Land Area }\left(\mathrm{km}^{2}\right)\end{array}$ & $\begin{array}{l}\text { PV Average } \\
\text { Capacity } \\
\text { Factor }\end{array}$ & $\begin{array}{l}\text { Available Wind } \\
\text { Land Area } \\
\left(\mathrm{km}^{2}\right)\end{array}$ & $\begin{array}{l}\text { Wind Average } \\
\text { Capacity Factor }\end{array}$ \\
\hline \hline 1 & BIA/Navajo & 1.40 & 0.26 & 14.48 & 0.39 \\
2 & BLM & 18.00 & 0.25 & 17.60 & 0.32 \\
3 & BIA/Duck Valley & 2.67 & 0.22 & 15.44 & 0.32 \\
4 & BLM & 4.16 & 0.22 & 17.32 & 0.34 \\
5 & BIA/Wind River & 6.11 & 0.23 & 16.52 & 0.41 \\
6 & BLM & 4.69 & 0.22 & 18.48 & 0.32 \\
\hline
\end{tabular}

BLM and tribal lands are being explored for widespread deployment of renewable technologies (BLM 2012). ${ }^{3}$ This makes tribal lands attractive for this study, but the local benefits may differ due to specific project development characteristics.

Two deployment scenarios were evaluated on each land parcel: development of a 10-MW PV plant and development of wind across the developable land area at a density of 5 $\mathrm{MW} / \mathrm{km}^{2}$. The solar scenario assumed a PV density of $48 \mathrm{MW} / \mathrm{km}^{2}$. The wind scenario assumed deployment of International Electrotechnical Commission class 2 wind turbines at $80 \mathrm{~m}$ hub height in calculating the gross capacity factor.

\section{Analysis of MMSA Indicators at Potential Deployment Sites Energy Affordability}

The LCOE for each project was calculated assuming industry-reported capital and operating costs and a discount rate of 3\%, following the simplified LCOE methodology reported by NREL (2012). The overnight capital costs, fixed operating costs, and variable operating costs were obtained from NREL's Transparent Cost Database (OpenEI 2012). The median value for the technology-specific cost was selected in most cases; the variable operating costs for onshore wind only reported three values, and the intermediate value was used in the analysis.

To ensure consistency with values reported previously, these values were compared against those reported in a November 2010 report on LCOE (Tidball et al. 2010), which asserted a project lifetime of 30 years. This assumption was used in the cost calculations. The cost data are presented in Table 3, and the calculated LCOE by technology and site are presented in Table 4.

3 Learn more about these efforts at http://apps1.eere.energy.gov/tribalenergy/,

http://www1.eere.energy.gov/tribalenergy/guide/cs_wind_opportunities.html, and http://www.nrel.gov/docs/fy14osti/61395.pdf 
Table 3. Technology Costs Used to Calculate LCOE

\begin{tabular}{|lll|}
\hline Cost Category & Onshore Wind & Solar PV \\
\hline \hline Overnight Capital Costs $(\$ / \mathrm{kW})$ & $\$ 1,980.00$ & $\$ 5,200.00$ \\
Fixed Operating Costs $(\$ / \mathrm{kW}-\mathrm{year})$ & $\$ 27.26$ & $\$ 16.00$ \\
Variable Operating Costs $(\$ / \mathrm{kWh})$ & $\$ 0.012$ & $\$ 0.000$ \\
\hline
\end{tabular}

Table 4. LCOE for Onshore Wind and Solar PV at Six Case Study Sites

\begin{tabular}{|cll|}
\hline Area ID & $\begin{array}{l}\text { Onshore Wind } \\
\text { LCOE }(\$ / \mathrm{kWh})\end{array}$ & $\begin{array}{l}\text { Solar } \mathrm{PV} \\
\text { LCOE }(\$ / \mathrm{kWh})\end{array}$ \\
\hline \hline 1 & $\$ 0.049$ & $\$ 0.12$ \\
2 & $\$ 0.058$ & $\$ 0.13$ \\
3 & $\$ 0.058$ & $\$ 0.15$ \\
4 & $\$ 0.055$ & $\$ 0.15$ \\
5 & $\$ 0.048$ & $\$ 0.14$ \\
6 & $\$ 0.058$ & $\$ 0.15$ \\
\hline
\end{tabular}

\section{Energy Diversity}

In order to compute the baseline Shannon Diversity Indicator and the change in value under the proposed deployment scenarios, an appropriate system boundary must be established. One option explored was to look at the generation profile of the nearest likely off-take utility. Assuming that this would be the nearest large utility, the three potential off-takers identified were Idaho Power, PacifiCorp, and APS. Delivered electricity by energy source was accessible only for Idaho Power as part of their Integrated Resource Plan (IRP) (2011). These values were compared with data available in the Ventex database, which reports for all three utilities, but this database only reports generation by owner, and so it does not capture energy delivered to utility customers as part of long-term power purchase agreements.

In order to capture local diversity issues in the absence of this information, the baseline Shannon Diversity Index was calculated for each state based on reported U.S. Energy Information Administration (EIA) data (EIA 2010). The value calculated for Idaho, 0.636 , differs somewhat from the value calculated using generation values reported in Idaho Power's 2011 IRP, 0.837. The disparity between Wyoming and PacfiCorp, the possible off-take utility for projects in that state, would likely be even greater given that PacifiCorp operates across several western states.

To compute the diversity index under the different deployment scenarios, the expected new generation was added to EIA's 2010 generation values. The expected generation values, assuming maximum wind deployment and $10 \mathrm{MW}$ of deployed solar PV, are reported in Table 5 . 
Table 5. Potential Solar and Wind Generation on Case Study Sites

\begin{tabular}{|clll|}
\hline Area ID & $\begin{array}{l}\text { Potential Solar } \\
\text { Generation (MWh) }\end{array}$ & $\begin{array}{l}\text { Installed Wind Capacity } \\
(\mathrm{MW})\end{array}$ & $\begin{array}{l}\text { Potential Wind } \\
\text { Generation (MWh) }\end{array}$ \\
\hline 1 & 22,545 & 69.0 & 238,097 \\
2 & 21,717 & 87.0 & 243,878 \\
3 & 19,384 & 76.5 & 214,445 \\
4 & 19,369 & 85.5 & 255,442 \\
5 & 20,007 & 81.0 & 290,000 \\
6 & 19,016 & 91.5 & 256,493 \\
\hline
\end{tabular}

The solar scenarios assume a 10-MW project, and the wind scenarios show the estimated installed capacity and resultant generation estimates.

Table 6 presents the baseline diversity indicator for the states and the percentage change in diversity indicator under solar and wind project development scenarios at the six land parcels. As the wind projects result in much greater electricity generation, they have a greater impact on system diversity. The greatest change in the diversity indicator$3.13 \%$ - was realized in the Idaho wind scenario on land parcel 4, corresponding to a reduced share of hydropower generation from $82.2 \%$ to $81.6 \%$. In the Wyoming scenarios (land parcels 5 and 6), even the highest levels of deployment only reduced the share of coal from $91.3 \%$ to $91.2 \%$. In Arizona (parcels 1 and 2), the additions of wind and solar realized the smallest changes to the already somewhat diverse system.

Table 6. Baseline Diversity Indicator for Each Case Study Site and the Percent Change in Diversity Indicator under Wind and Solar Project Development Scenarios

\begin{tabular}{|clll|}
\hline & $\begin{array}{l}\text { Baseline } \\
\text { Shannon } \\
\text { Land Parcel }\end{array}$ & $\begin{array}{l}\text { Diversity Indicator } \\
\text { Dhange Under } \\
\text { Solar Scenario } \\
(\%)\end{array}$ & $\begin{array}{l}\text { Diversity Indicator } \\
\text { Change Under Wind } \\
\text { Scenario (\%) }\end{array}$ \\
\hline \hline 1 & 1.25 & 0.04 & 0.32 \\
2 & 1.25 & 0.04 & 0.32 \\
3 & 0.64 & 0.74 & 2.65 \\
4 & 0.64 & 0.74 & 3.13 \\
5 & 0.35 & 0.37 & 1.34 \\
6 & 0.35 & 0.35 & 1.19 \\
\hline
\end{tabular}

\section{Climate Friendliness}

In the absence of specific emission values for a given project, a prospective look at the likely climate impacts could use the most recent, published reports of the life cycle GHG emissions normalized to production amounts. In this case, we use the median values by technology reported in the IPCC SRREN. For all solar project scenarios, this corresponds to a value of $46 \mathrm{~g} \mathrm{CO}_{2}$-eq/ $\mathrm{kWh}$, and for all wind projects, the GHG emissions are $12 \mathrm{~g}$ $\mathrm{CO}_{2}-\mathrm{eq} / \mathrm{kWh}$. 


\section{Water Conservation}

Considering the example locations in this study, water availability varies greatly from site to site (Figure 4). Sites 1, 2, and 6 have relatively little to no availability of surface water, and sites 2, 3, 4, and 6 have relatively little to no availability of groundwater. Sites 1 and 2 have substantial municipal wastewater and/or brackish groundwater resources, which could be utilized to offset freshwater demands.

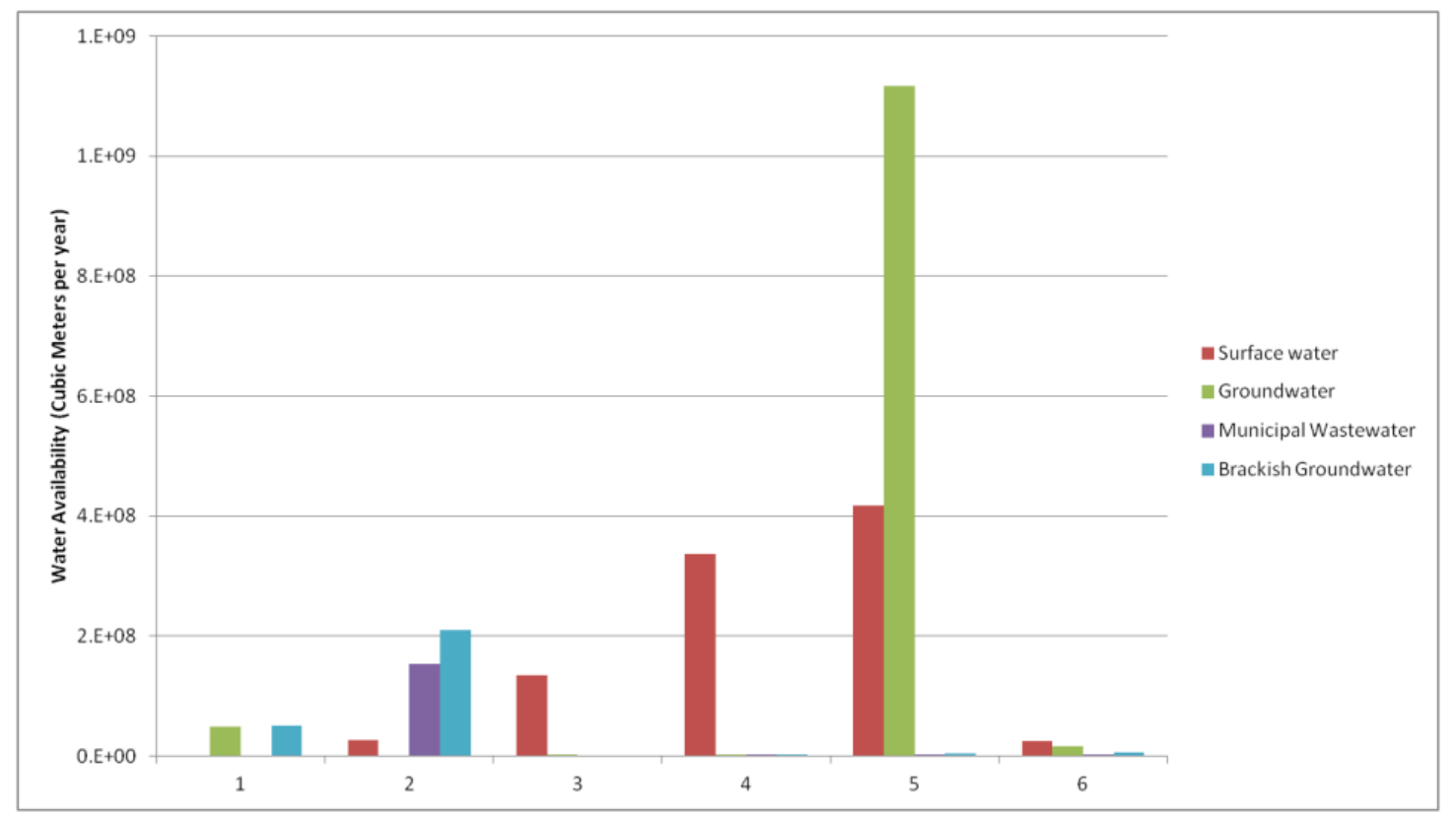

Figure 4. Water availability by source for six study regions

Given projected annual energy output for the two energy technologies considered here (as shown in Table 5), we calculate total annual water impacts based on established water consumption rates for PV technologies (DOE 2012). Wind has no operational water uses, and PV systems' low operational water uses lead to relatively minor water consumption impacts at each site (Figure 5). 


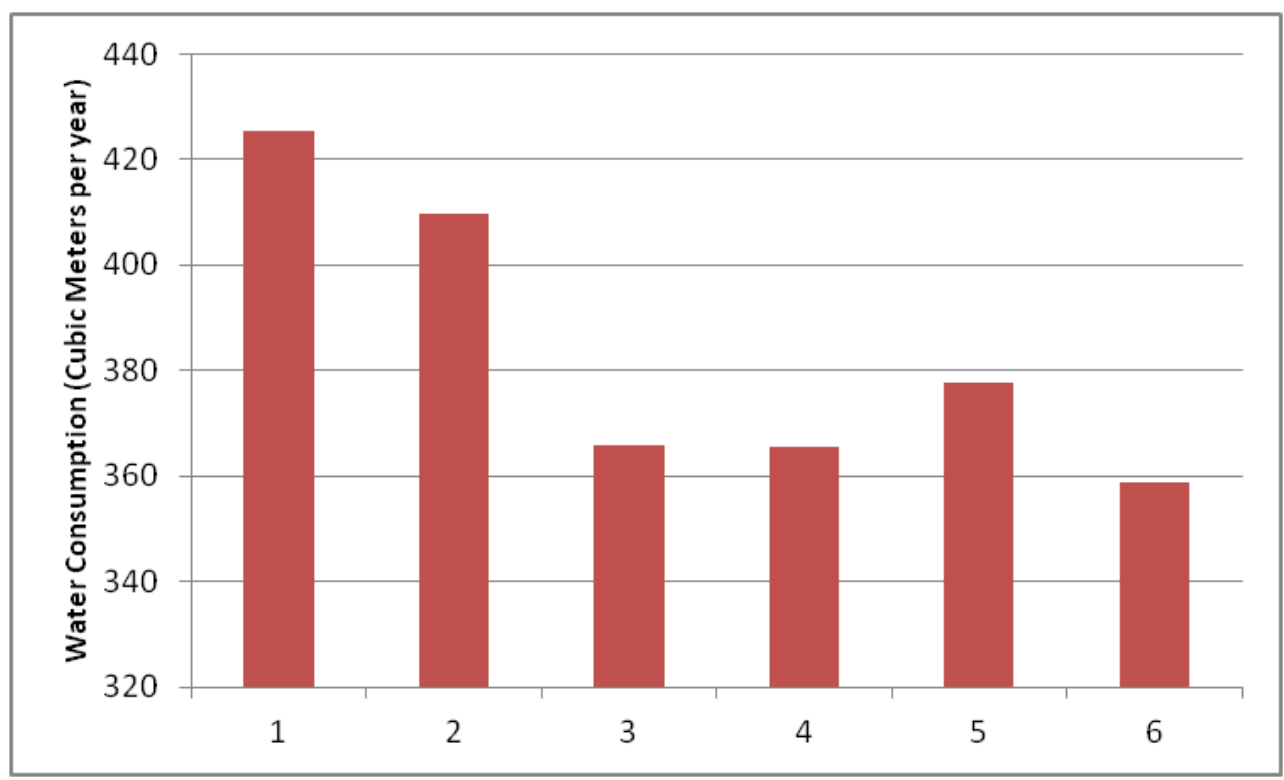

Figure 5. Water consumption by site for utility-scale PV installation

Water consumption from these two alternatives can also be analyzed in the context of other electricity generating technologies. Utilizing average annual energy output for the PV systems (20,000 MWh) and wind systems (250,000 MWh) for all sites, we compare the water consumption impacts of other electricity technologies that could potentially meet that level of generation using established water consumption values (Macknick et al. 2011). Overall, wind and PV water uses are negligible compared to other electricity generating technologies. Concentrated solar power (CSP) systems and coal plants with carbon capture and storage (CCS) technologies that utilize cooling towers have the highest relative water consumption impacts (Figure 6). 


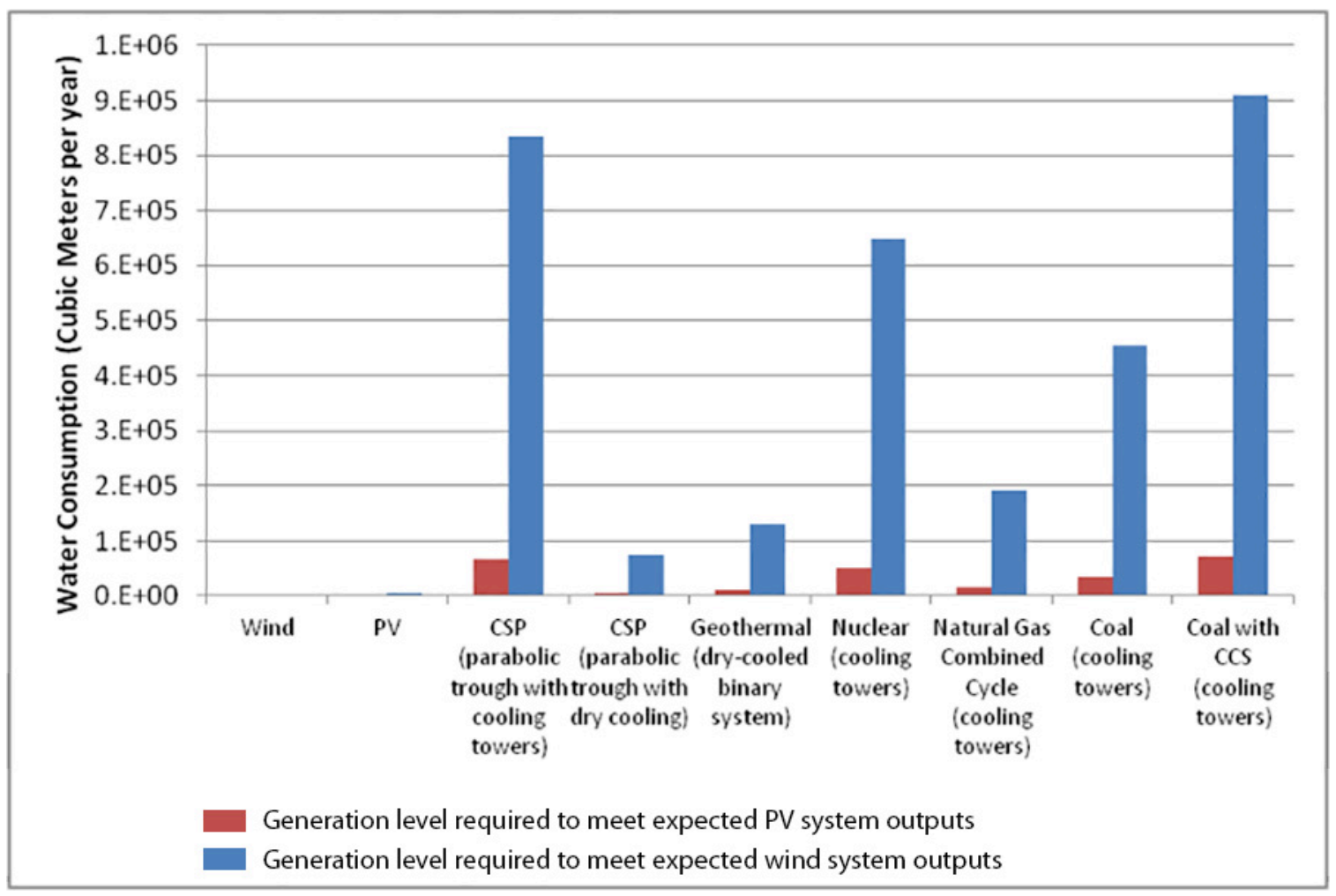

Figure 6. Water consumption impacts of a variety of electricity generating technologies

For these sites the impact on local water availability from PV and wind systems would be relatively minor, yet greater impacts could occur from development of other electricity generating technologies.

\section{Safety}

For the projects under evaluation here, project safety was measured using the IPCCpublished values for fatalities of severe incidents as a proxy (IPCC 2011). ${ }^{4}$ The only reported value for PV was for crystalline silicon, and this value, 0.000245 fatalities/GWeyear, was assigned to the potential PV projects. Two values were reported for onshore wind, one each for Denmark and the United Kingdom. The average of these values, 0.00415 fatalities/GWe-year, was assigned for the potential wind projects.

\section{Local Employment Impacts}

To assess local employment impacts, labor force values by county were obtained from the U.S. Bureau of Labor Statistics (BLS 2012). The average of the labor force data by county reported for the period April 2011 to May 2012 was used. Direct jobs for each of the project deployment scenarios were estimated by obtaining operation and maintenance job values from a published review of renewable energy jobs studies (Wei et al. 2010).

\footnotetext{
${ }^{4}$ Fatality rates consider the full energy chain, noting that accidents can happen during any stage from exploration, extraction, and processing for fossil fuels to long distance transport and disposal. Estimates for renewable energy technologies are based on available accident statistics, literature review, and expert judgment because of limited historical experience and data (PSI n.d.).
} 
The values reported for solar PV and wind in Table 2 of Wei et al. (2010) were averaged, scaled to the project size being evaluated (10 MW for solar; see Table 5 for wind project installed capacity), and rounded to the nearest integer value. The local employment impact was calculated by dividing the anticipated direct local jobs by the average labor force. Table 7 shows the labor force, expected direct jobs, and job impact for the six land parcels under both the solar and wind project scenarios.

Table 7. Local Employment Impacts from Deployment of Wind and Solar Projects at Six Land Parcels

\begin{tabular}{|c|c|c|c|c|c|c|}
\hline $\begin{array}{l}\text { Land } \\
\text { Parcel }\end{array}$ & County & $\begin{array}{l}\text { Labor Force; } \\
\text { Average April } \\
\text { 2011-May } \\
2012\end{array}$ & $\begin{array}{l}\text { Direct } \\
\text { Jobs } \\
\text { Created } \\
\text { Solar }\end{array}$ & $\begin{array}{l}\text { Direct } \\
\text { Jobs } \\
\text { Created } \\
\text { Wind }\end{array}$ & $\begin{array}{l}\text { Local } \\
\text { Emp } \\
\text { Impact } \\
\text { Solar (\%) }\end{array}$ & $\begin{array}{l}\text { Local Emp } \\
\text { Impact } \\
\text { Wind (\%) }\end{array}$ \\
\hline 1 & Coconino, AZ & 72,139 & 5 & 17 & 0.01 & 0.02 \\
\hline 2 & Pinal, AZ & 139,144 & 5 & 21 & 0.00 & 0.02 \\
\hline 3 & Owyhee, ID & 4,540 & 5 & 19 & 0.11 & 0.42 \\
\hline 4 & Owyhee, ID & 4,540 & 5 & 21 & 0.11 & 0.46 \\
\hline 5 & Fremont, WY & 19,725 & 5 & 20 & 0.03 & 0.10 \\
\hline 6 & Fremont, WY & 19,725 & 5 & 22 & 0.03 & 0.11 \\
\hline
\end{tabular}

\section{MMSA Analysis and Presentation}

To facilitate comparisons and trade-off analysis, this section tabulates all of the metrics discussed and illustrates the findings with the MMSA visual. Table 8 presents a summary of the MMSA indicators, metrics used, and minimum and maximum values applied for indicator evaluation. Table 9 shows the metric value calculated for each scenario and land parcel. Figure 7 presents the findings applied within the MMSA visual framework for all scenarios.

Table 8. Summary of MMSA Indicators, Metrics, and Range of Values

\begin{tabular}{|l|l|l|l|l|l|l|}
\hline $\begin{array}{l}\text { MMSA } \\
\text { Indicator }\end{array}$ & $\begin{array}{l}\text { Energy } \\
\text { Affordability }\end{array}$ & $\begin{array}{l}\text { Energy } \\
\text { Diversity }\end{array}$ & $\begin{array}{l}\text { Climate } \\
\text { Friendliness }\end{array}$ & $\begin{array}{l}\text { Water } \\
\text { Conservation }\end{array}$ & Safety & $\begin{array}{l}\text { Local } \\
\text { Employment } \\
\text { Impacts }\end{array}$ \\
\hline Metric & $\begin{array}{l}\text { LCOE } \\
\text { (USD/kWh) }\end{array}$ & $\begin{array}{l}\text { Change in } \\
\text { diversity } \\
\text { indicator (\%) }\end{array}$ & $\begin{array}{l}\text { GHG emission } \\
(\mathrm{g}-\end{array}$ & $\begin{array}{l}\text { Available } \\
\mathrm{CO}_{2} \text { eq/kWh) } \\
\text { water used for } \\
\text { plant operation } \\
\text { (fraction) }\end{array}$ & $\begin{array}{l}\text { Fatalities from } \\
\text { severe } \\
\text { incidents } \\
\text { (fatalities/GW- } \\
\text { yr) }\end{array}$ & $\begin{array}{l}\text { Contribution to } \\
\text { county } \\
\text { employment } \\
\text { (\%) }\end{array}$ \\
\hline Minimum & 0.39 & -5 & 1,000 & 1 & 0.120000 & 0 \\
\hline Maximum & 0 & 5 & 0 & 0 & 0.000248 & 1 \\
\hline
\end{tabular}


Table 9. Metric Values for Each Scenario and Land Parcel

\begin{tabular}{|c|c|c|c|c|c|c|c|}
\hline $\begin{array}{l}\text { Deployment } \\
\text { Scenario }\end{array}$ & Land Parcel & $\begin{array}{l}\text { LCOE } \\
\text { (USD/kWh) }\end{array}$ & $\begin{array}{l}\text { Change in } \\
\text { Diversity } \\
\text { Indicator } \\
(\%)\end{array}$ & $\begin{array}{l}\mathrm{GHG} \\
\text { Emission } \\
\left(\mathrm{g}-\mathrm{CO}_{2} \mathrm{eq} /\right. \\
\mathrm{kWh})\end{array}$ & $\begin{array}{l}\text { Available } \\
\text { Water Used } \\
\text { for Plant } \\
\text { Operations } \\
\text { (fraction) }\end{array}$ & $\begin{array}{l}\text { Fatalities } \\
\text { from Severe } \\
\text { Incidents } \\
\text { (fatalities/G } \\
\text { W-yr) }\end{array}$ & $\begin{array}{l}\text { Contribution } \\
\text { to County } \\
\text { Employ- } \\
\text { ment (\%) }\end{array}$ \\
\hline \multirow{6}{*}{ Solar } & 1 & 0.12 & 0.04 & 46 & 0 & 0.000245 & 0.01 \\
\hline & 2 & 0.13 & 0.04 & 46 & 0 & 0.000245 & 0.00 \\
\hline & 3 & 0.15 & 0.74 & 46 & 0 & 0.000245 & 0.11 \\
\hline & 4 & 0.15 & 0.74 & 46 & 0 & 0.000245 & 0.11 \\
\hline & 5 & 0.14 & 0.37 & 46 & 0 & 0.000245 & 0.03 \\
\hline & 6 & 0.15 & 0.35 & 46 & 0 & 0.000245 & 0.03 \\
\hline \multirow{6}{*}{ Wind } & 1 & 0.05 & 0.32 & 12 & 0 & 0.004150 & 0.02 \\
\hline & 2 & 0.06 & 0.32 & 12 & 0 & 0.004150 & 0.02 \\
\hline & 3 & 0.06 & 2.65 & 12 & 0 & 0.004150 & 0.42 \\
\hline & 4 & 0.05 & 3.13 & 12 & 0 & 0.004150 & 0.46 \\
\hline & 5 & 0.05 & 1.34 & 12 & 0 & 0.004150 & 0.10 \\
\hline & 6 & 0.06 & 1.19 & 12 & 0 & 0.004150 & 0.11 \\
\hline
\end{tabular}

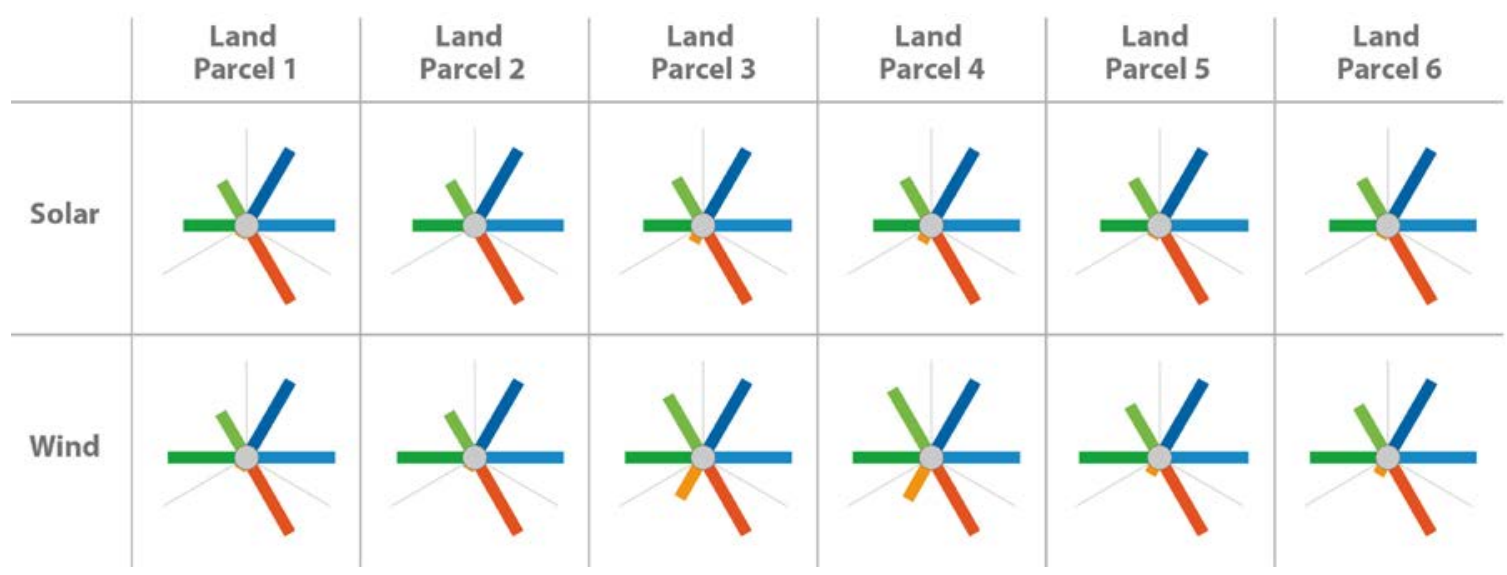

Legend

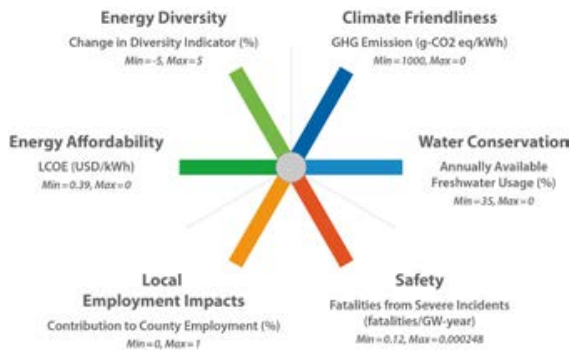

Figure 7. MMSA visual showing case study findings 


\section{Discussion}

In the MMSA literature, some sustainability domains are relatively well-researched, with well-vetted quantification methods, such as GHG emissions and water use. However, this is not the case for other metrics, such as the social impacts of energy systemsquantifying their potential impacts can be complex, and the studies that do exist sometimes rely only on expert opinion or general perceptions rather than quantitative analytical approaches. For example, one recent study of the European Union (EU) energy system (Carrera and Mack 2010) involved a thorough review of the social indicator research to identify energy-relevant impact indicators, but it relied on surveys of expert opinion to assign values to different social impact categories.

Working in this multivariable, multidimensional, and relatively new field of sustainability science presents significant challenges that one would expect from a frontier field. Solid understanding of these challenges is essential to properly apply the proposed MMSA tool and present results. One of those challenges relates to the interdisciplinary nature of this broad area and the fact that, for the past several decades, each pertinent discipline has developed a unique language to efficiently communicate advances in the field among their peers.

This paper presents one potential approach to synthesizing information from disparate disciplines and presenting it in a way that is accessible to a diverse set of stakeholders, and which offers the benefit of a tractable visual interpretation for a wide range of audiences. The tool could be further refined to account for uncertainty or to include dimensions that are limited strictly to qualitative assessment. It is important to note that parameter choices and the determination of maximum and minimum values for each indicator affect interpretation of results. For instance, a ruler scaled such that all impacts are likely to appear small could be misleading. Clearly detailing the underlying data and framework can help to ensure transparency and allow for critical analysis by interested stakeholders, as well as further refinements to meet unique project needs. As the proposed MMSA tool is used and results are presented to diverse audiences, detailing the underlying assumptions and data that ultimately drive the implications of results will be critical for interpretation purposes.

Lastly, consideration of the specific priorities and perspective of the decision-maker using the tool will likely influence the indicators selected for the analysis as well as the prioritization of indicators within the framework. For example, a decision-maker that is involved in investment planning or project development might be less concerned with climate friendliness or employment benefits relative to a policymaker. While the objective of this initial pilot was to demonstrate the proposed tool's applicability specifically from a policymaker's perspective, the tool was designed to be flexible and applicable to a wide range of potential users. 


\section{References}

Afgan, N.H.; Carvalho, M.G.; Havonov, N.V. (2000). "Energy system assessment with sustainability indicators.” Energy Policy (28:9); pp. 603-612.

Afgan, N.H.; Carvalho, M.G. (2002). "Multi-criteria assessment of new and renewable energy power plants." Energy (27:8); pp. 739-755.

Awerbuch, S. (2004). Portfolio-Based Electricity Generation Planning: Implications for Renewables and Energy Security. London: REEEP Environmental Policy Department.

Begic, F.; Afgan, N.H. (2007). "Sustainability assessment tool for the decisions making in selection of energy system-Bosnian case.” Energy (32:10); pp. 1979-1985.

Bureau of Labor Statistics (BLS). (2012). Labor force data by county, not seasonally adjusted. September 2011-October 2012. Accessed March

2014: http://www.bls.gov/lau/laucntycur14.txt.

Bureau of Land Management (BLM). (2012). "New Energy for America." Accessed March 2014: http://www.blm.gov/wo/st/en/prog/energy/renewable energy.html.

Convertino, M.; Baker, K.M.; Vogel, J.T.; Lu, C.; Suedel, B.; Linkov, I. (2013). "Multicriteria decision analysis to select metrics for design and monitoring of sustainable ecosystem restorations." Ecological Indicators (26); pp;. 76-86.

Dey, C. (undated). Integrated Sustainability Analysis. The University of Sydney. Accessed October 2014: http://www.isa.org.usyd.edu.au/research/tblone.shtml.

Electric Power Research Institute (EPRI). (2003). Use of Degraded Water Sources as Cooling Water in Power Plants. Technical Report 1005359. Palo Alto, CA: Electric Power Research Institute.

Elkington, J. (1994). "Towards the Sustainable Corporation: Win-Win-Win Business Strategies for Sustainable Development." California Management Review (36:2) pp. 90100 .

Energy Information Administration (EIA). (2010). Electric Power Sector Consumption Estimates, 2010 (Trillion Btu). Accessed March

2014: http://www.eia.gov/beta/state/seds/data.cfm?incfile=sep sum/html/sum btu eu.ht $\underline{\mathrm{ml}}$.

Evans, A.; Strezov, V.; Evans, T.J. (2009). "Assessment of sustainability indicators for renewable energy technologies." Renewable and Sustainable Energy Review (13); pp. 1082-1088.

Francis, C. (undated). Cobweb Polygons (Spider Diagrams) for Visual Display of Sustainability. University of Nebraska Sustainable Agriculture. Accessed March 2014: http://sustainableag.unl.edu/pdf/sustainability polygon.pdf 
Gallego Carrera, D; Mack, A. (2010). "Sustainability assessment of energy technologies via social indicators: Results of a survey among European energy experts." Energy Policy (38:2); pp. 2030-2039.

Goedkoop, M.; De Schryver, A.; Oele, M.; Durksz, S.; de Roest, D. (2010). "Introduction to LCA with SimaPro 7." Amersfoort, The Netherlands: PRé Consultants.

Gross, R.; Blyth, W.; Heptonstall, P. (2009). "Risks, revenues, and investment in electricity generation: Why policy needs to look beyond costs." Energy Economics (32); pp. 786-804.

Hofstetter, P. (1998). Perspectives in Life Cycle Impact Assessment; A structured approach to combining models of the technosphere, ecosphere and valuesphere. New York, NY: Kluwer Academic Publishers.

Idaho Power Company. (2011). 2011 Integrated Resource Plan. Accessed September 2014: http://www.idahopower.com/pdfs/AboutUs/PlanningForFuture/irp/2011/2011IRPF INAL.pdf.

Intergovernmental Panel on Climate Change (IPCC). (2011). IPCC Special Report on Renewable Energy Sources and Climate Change Mitigation. Prepared by Working Group III of the Intergovernmental Panel on Climate Change. Edenhofer, O; Pichs-Madruga, R.; Sokona, Y.; Seyboth, K.; Matschoss, P.; Kadner, S.; Zwickel, T.; Eickemeier, P.; Hansen, G.; Schlömer, S.; von Stechow, C., eds. Cambridge, United Kingdom and New York, NY: Cambridge University Press.

Jansen, J.; van Arkel, W.G.; Boots, M.G. (2004). "Designing Indicators of Long-term Energy Supply Security." ECN-C--04-007. Petten, The Netherlands: ECN. Accessed March 2014: http://www.ecn.nl/docs/library/report/2004/c04007.pdf.

Lior, N. (2007). “About sustainability metrics for energy development.” Prepared for Sustainable energy development status panel at the NSF Workshop Frontiers in Transport Phenomena Research \& Education: Energy Systems, Biological Systems, Security, Information Technology and Nanotechnology, May 17-18, 2007, University of Connecticut - Storrs.

Lopez, A.; Roberts, B.; Heimiller, D.; Blair, N.; Porro, G. (2012). U.S. Renewable Energy Technical Potentials: A GIS-Based Analysis. NREL/TP-6A20-51946. Golden, CO: National Renewable Energy Laboratory.

Macknick, J.; Newmark, R.; Heath, G.; Hallett, K. (2011). 2011: A Review of Operational Water Consumption and Withdrawal Factors for Electricity Generating Technologies. NREL/TP-6A20-50900. Golden, CO: National Renewable Energy Laboratory.

National Renewable Energy Laboratory (NREL). (2012). "Simple Levelized Cost of Energy (LCOE) Calculator

Documentation." http://www.nrel.gov/analysis/tech_lcoe_documentation.html. 
OpenEI. (2012). “Transparent Cost Database.” DOE/NREL. Accessed July 20, 2012: http://en.openei.org/apps/TCDB/.

Paul Scherrer Institut (PSI). (undated). "Comparative Risk Assessment and the ENSAD Database.” Accessed August 2014: http://www.psi.ch/ta/risk-assessment.

Pehnt, M. (2006). "Dynamic life cycle assessment (LCA) of renewable energy technologies.” Renewable Energy (31:1); pp. 55-71.

Seaber, P.; Kapinos, F.; Knapp, G. (1987). Hydrologic Unit Maps. Denver, CO: United States Geological Survey. Accessed March 2014: ftp://ftp.ftw.nrcs.usda.gov/wbd/.

Sovacool, B.K., ed. (2010). The Routledge Handbook of Energy Security. New York: Routledge USA.

Tidball, R.; Bluestein, J.; Rodriguez, N.; Knoke, S. (2010). Cost and Performance Assumptions for Modeling Electricity Generation Technologies. NREL/SR-6A20-48595. Work performed by ICF International, Fairfax, VA. Golden, CO: National Renewable Energy Laboratory.

Tidwell, V.; Moreland, B.; Zemlick, K.; Roberts, B.; Passell, H.; Jensen, D.; Forsgren, C.; Sehlke, G.; Cook, M.; King, C.; Larsen, S. (2014). "Mapping water availability, projected use and cost in the western United States." Environmental Research Letters (9:6).

United States Department of Energy (DOE). (2012). SunShot Vision Study. DOE/GO102012-3037. Washington, D.C.: U.S. Department of Energy, Office of Energy Efficiency and Renewable Energy.

Wei, M.; Patadiab, S.; Kammena, D. (2010). "Putting renewables and energy efficiency to work: How many jobs can the clean energy industry generate in the US?" Energy Policy (38:2); pp. 919-931. 